\title{
LAS PRIMERAS ORDENANZAS MUNICIPALES DE VILLENA (1440-1445)
}

\author{
Alfonso Franco Silva \\ Antonio Moreno Ollero
}

\section{INTRODUCCIÓN}

A comienzos del año 1440 el rey Juan II concedía la villa de Villena a uno de sus hombres de confianza, el doctor Pero Yáñez, conocido también por Periáñez. Este personaje procedía de una familia oriunda de Galicia pero asentada en Toro, según M. ${ }^{a}$ José Sanz, al menos desde dos generaciones antes (1). Doctor en leyes, como su hermano Juan Alfonso, hizo una larga y fructuosa carrera burocrática en las oficinas de la Corte castellana. Pronto se convierte en oidor de la Real Audiencia y refrendario de los diplomas de Juan II. Don José María Soler en su espléndido trabajo La donación de Villena al Dr. Periánez en 1440 afirma que la primera noticia que conocemos acerca de este personaje procede del año 1406 en que acude a las Cortes de Toledo convocadas por Fernando de Antequera tras la muerte de Enrique III (2). Aparece también en ese año como testigo, al ser oidor y refrendario, en el testamento otorgado por Enrique III (3). Sin embargo, Pero Yáñez era ya un hombre conocido en la Corte castellana en los últimos años del siglo XIV porque figura como testigo en un documento de 1398 conservado en el Archivo Ducal de Frías en el que aparece su nombre y su oficio de doctor refrendario del rey (4). Unos años después fue nombrado Canciller Mayor de la infanta Doña María que se convertiría más tarde, tras su matrimonio con Alfonso V, en reina de Aragón (5). For- 
maba parte por tanto del grupo de funcionarios de la Corte castellana. Este grupo de burócratas que se convertirían años más tarde en fieles partidarios del Condestable Luna y harán carrera a la sombra de su amo y al amparo de su privanza, lo formaban hombres de origen oscuro como Pero Yáñez, el contador mayor Alfonso Pérez de Vivero, Fernán López de Saldaña y Fernando de Ribadeneira (6). Algunos de ellos aprovecharon su posición y su constante presencia junto al monarca para acceder a la pequeña nobleza. Este fue el caso del personaje que nos ocupa, el doctor Pero Yáñez que en 1428, bajo la protección de don Alvaro de Luna, pasa a ocupar un puesto en el Consejo Real, organismo que dirigía con el monarca la política del reino castellano. Este puesto, de gran responsabilidad en la administración, que el doctor conservó ininterrumpidamente desde 1428 a 1440 y entre 1442 y julio de 1443, le fue entregado por el Condestable Luna con el objetivo de convertirle en pieza clave para, a través del Consejo, controlar de forma total el poder en Castilla.

Partidario de Don Alvaro de Luna, servidor fiel y disciplinado de Juan II, el doctor Pero Yáñez alcanzó en 1440 el objetivo perseguido con tenacidad desde muchos años antes: convertirse en señor feudal de villas y vasallos. En efecto, en ese año el oscuro y humilde funcionario pasa a ser señor de una villa tan importante como Villena. Pero Yáñez había pedido con insistencia al rey una villa en tierras de Extremadura con la secreta intención de crearse un dominio propio en esa zona. El monarca le prometió la villa extremeña de Granadilla, pero al encontrarse ésta en poder del infante Don Enrique de Aragón, Juan II no quiso indisponerse con su primo en unos momentos en que precisamente acababa de reconciliarse con él y su hermano Juan de Navarra en la Concordia de Castronuño y en su lugar y hasta que cumpliese la promesa, le concedió Villena (7). Al entregar esta última villa a Pero Yáñez, Juan II y tras él su mentor Alvaro de Luna, pensaban a juicio de Aurelio Pretel, interponer un enclave controlado por un hombre fiel a la Corona entre las fuerzas enemigas de Juan de Navarra, que ocupaban una parte de las tierras que habían pertenecido al antiguo Marquesado de Villena, y los auxilios que podía recibir este último del reino de Valencia (8). A pesar de estos peligros el doctor Pero Yáñez pudo afianzarse y logró consolidar su dominio en esta villa hasta su muerte.

El objetivo que perseguimos al escribir este trabajo no es otro que el análisis de todos los acontecimientos y del señorío que ejerció sobre la villa Pero Yáñez así como su gran labor administrativa que se tradujo en la concesión a Villena de sus primeras ordenanzas municipales, al menos las más antiguas de las que tenemos noticia. La documentación que hemos manejado es enormemente rica y variada, y procede de los fondos del 
Marquesado de Villena que se hallan en el Archivo Ducal de Frías, ubicado en el castillo cordobés de Montemayor. Hemos creído conveniente aportar una serie de documentos originales e inéditos que arrojan mucha luz para la comprensión correcta de estos años decisivos para la historia de Villena. Entre estas piezas de singular valor incluimos el texto original de las ordenanzas, una interesante serie de cartas del Adelantado de Murcia Alfonso Yáñez Fajardo al señor de Villena y al concejo de la villa que proporcionan una riquísima información sobre la situación de esa villa y finalmente, los documentos originales que nos transmiten datos sobre la confiscación de la villa a los hermanos de Pero Yáñez y la entrega de la misma a Juan Pacheco que recibe además el título de marqués de Villena.

\section{VILLENA. DEL DOCTOR PERO YÁÑEZ A LOS DOMINIOS DE JUAN PACHECO}

Hasta el año 1440 en que le fue entregada a Pero Yáñez, Villena había sido la capital del gran marquesado al que dio título la propia villa, una extensa demarcación territorial creada a fines de siglo XIII y que osciló a lo largo del siglo XIV y buena parte del XV entre el realengo y el señorío. EI profesor José Luis Pastor Zapata en un extenso y precioso trabajo ha definido al marquesado como un "apanage", en el sentido francés de este concepto, es decir, un gran estado territorial que la monarquía reservaba para dotar a sus segundones desfavorecidos por las leyes de la herencia (9). En efecto, el señorío de Villena se fue constituyendo lentamente desde la segunda mitad del siglo XIII en que pasó a poder del infante Don Manuel, hijo menor de Fernando III, hasta finales de esa centuria, época en que el gobierno y administración de este estado lo ejerce su hijo el famoso escritor Don Juan Manuel, Adelantado Mayor del reino de Murcia. A mediados del siglo XIV el marquesado, tras la extinción del linaje Manuel, retornó a la Corona y sólo saldría de los dominios realengos cuando Enrique de Trastámara derrota y da muerte a su hermanastro Pedro I en Montiel. EI nuevo monarca concedió el marquesado a uno de sus más firmes partidarios el infante don Alfonso de Aragón y en sus dominios se mantendría hasta fines de la centuria en que de nuevo volvió a la Corona tras ser confiscado por Enrique III a los herederos del aragonés (10). No nos detenemos en el análisis de estos acontecimientos pues han sido muy bien estudiados por Emilio Mitre, Aurelio Pretel y José M. ${ }^{a}$ Soler (11).

Cuando en 1440 Pero Yáñez recibe la villa de Villena, segregada de los territorios que habían formado el marquesado del mismo nombre, el se- 
ñorío seguía perteneciendo al realengo, a pesar de que durante algunos años (1420-1423) lo había poseído el infante Don Enrique de Aragón como dote de su esposa Doña Catalina, hermana de Juan II de Castilla (12). En 1439, un año antes de que la villa pasase a Pero Yáñez, Juan II se comprometió a entregar las tierras del marquesado de Villena a su primo Juan de Navarra que las recibiría en concepto de dote por el matrimonio de su hija Blanca con el príncipe de Asturias, el futuro Enrique IV (13). El pacto firmado en Toledo no se cumplió y Villena continuó en poder de Juan II hasta 1440 en que le fue concedida a Pero Yáñez por las razones ya expuestas.

El monarca al donar la villa a su funcionario lo hace para que la tenga por juro de heredad y la pueda transmitir en mayorazgo a su hijo primogénito, su doncel Juan de Ulloa, y tras su muerte a todos "los que d'él descendieren legítimos de legítimo matrimonio nascidos todauia el mayor antes que el menor e todauia que sean machos e non fembras" y si carece de hijos varones Villena pasaría al segundo hijo del doctor Rodrigo de Ulloa (14). Juan II prohibe además a su servidor que venda o enajene Villena y ordena al concejo de ésta que reciba a Pero Yáñez por su señor y se someta a su jurisdicción.

El 11 de marzo de 1440 Pero Yáñez en una carta escrita desde Bonjlla de la Sierra encarga a Nicolás Rodríguez de Sevilla, escribano de cámara del rey, y al comendador Pedro de Soto que fuesen a Villena y tomen posesión de ella en su nombre. El doctor se justifica por no tomar posesión personalmente de su villa ya que se encuentra "ocupado al presente en otros muy arduos negocios al seruicio del rey" (15). El miércoles 6 de abril de ese mismo año los dos enviados del doctor tomaron posesión de la villa y le fueron entregadas todas las llaves de las tres puertas de Villena: la de Almansa, la del Molino y la de Plaza (16).

Había que organizar el dominio recién adquirido de una villa rica e importante, enclavada además en una excelente posición estratégica a cabaIlo entre el reino de Castilla y el de Aragón. A tal efecto el 2 de mayo de 1440 en Tordesillas, Pero Yáñez determinó nombrar mayordomo de la villa a un hombre de su confianza, Alvar Ruiz, escribano del rey y vecino de Villena, para que en su nombre recaudase los derechos de almojarifazgo, salinas, censales de pan y maravedís, tierras, rentas de hornos y pinares y todas las otras rentas que tradicionalmente cobraba el señor (17).

Sin embargo, como muy bien ha puesto de relieve Aurelio Pretel, el doctor Pero Yáñez encontró algunas dificultades a la hora de afianzarse en su 
nueva posición (18). Los partidarios que el rey de Navarra tenía en Villena eran aún numerosos e importantes y esperaban la ocasión propicia para que la villa retornase de nuevo a su antiguo señor. Entre mayo y junio la situación en el interior de la villa distó mucho de ser tranquila. Así lo ponen de manifiesto las cartas que el Adelantado de Murcia Alfonso Yáñez Fajardo escribe entre abril y septiembre de 1440 al concejo de Villena y a los hombres de confianza de Pero Yáñez. El Archivo Ducal de Frías ha conservado por fortuna estos interesantes testimonios fechados unos en Murcia y otros en Molina, villa a la que se había retirado el Adelantado tras el estallido de un brote de peste en Murcia (19). El rey de Navarra había tratado de reducir paulatinamente la jurisdicción del Adelantado de Murcia en las tierras del antiguo marquesado de Villena (20). A tal efecto entre otras acciones contra el Adelantado, Juan de Navarra había nombrado gobernador del marquesado a su pariente y enemigo Diego Fajardo que desde el año 1440 va a tener una intervención muy activa en los acontecimientos que se desarrollaron en estas tierras (21). El Adelantado, partidario de Juan II de Castilla, vio con alivio la donación de Villena a un caracterizado realista como Pero Yáñez y se dispuso desde un principio a prestarle toda su ayuda y a lograr que consolidase su recién adquirido señorío. La creación de un foco realista en Villena, frente a otras villas como Yecla, Hellín y Sax, que obedecían al rey de Navarra, venía a favorecer los planes del Adelantado. De aquí que no puede resultar extraña su copiosa correspondencia con el concejo de Villena para evitar que esta villa se perdiese para el bando real y sobre todo su preocupación por desenmascarar y eliminar los posibles partidarios del rey de Navarra en la villa: en especial el descubrimiento de la traición al doctor Pero Yáñez de Juan Martínez de Mergelina, alcaide del castillo de Villena, que tras una fuerte pelea fue desalojado de la fortaleza por tropas enviadas en auxilio de la villa por el Adelantado. Las cartas más interesantes son las dirigidas por Alfonso Yáñez Fajardo el 4 de junio al concejo de Villena y el 30 de ese mismo mes al doctor Pero Yáñez. En la primera el Adelantado intenta dar ánimos y tranquilidad a la población de Villena haciéndole saber que se presta personalmente a defender la villa si ésta es atacada por las tropas leales al rey de Navarra, desmiente los falsos rumores propalados por el gobernador del Marquesado de que la villa sería sitiada bien pronto y les pide confianza en el alcaide del castillo, sospechoso para los vecinos y que a la postre, a pesar de la confianza depositada en él por Alfonso Yáñez, resultaría un traidor. Manifiesta su sincera preocupación por la suerte de la villa con palabras tales como éstas: "yo paso tan grand pena en mi voluntad como vosotros e más e non vos enbiar luego la gente que yo querria... porque yo so obligado a vosotros ca non lo puedo negar". En la carta que dirige el 30 de junio al doctor Pero Yáñez, el Adelantado de Murcia, tras hacerle saber que se ha retirado a su villa de Molina Seca por la peste que ha estallado en Murcia, le comunica las talas y daños que Villena había recibido a causa de 
la traición del alcaide del castillo Juan Martínez de Mergelina que al fin se desenmascaró como partidario que era desde hacía algún tiempo de Mosén Diego Fajardo, gobernador del marquesado. El Adelantado le confiesa con sinceridad que siempre le había creído leal a Pero Yáñez y que por tanto no había podido remediar esos daños. Alfonso Yáñez continúa relatando al doctor que gracias a la intervención del bachiller Alfonso Fernández de León, enviado por el rey con provisiones y gentes de armas, se había podido evitar que Villena capitulase y se entregase a los partidarios del rey de $\mathrm{Na}$ varra. El traidor había huido al reino de Aragón. Alfonso Yáñez pide al doctor que si le captura le ponga preso hasta que se logre la rendición del castillo de Villena que se encuentra todavía en poder del enemigo. Más aún Alfonso Yáñez insta a Pero Yáñez a que si captura al traidor alcaide, aunque recobre el castillo de su villa, le dé muerte porque tras dieciocho años al frente de ese oficio no merece más que morir. Finalmente le dice que por lo que respecta a la villa como tal se encuentra ahora segura y podrá defenderse de cualquier ataque que pudiera dirigirse contra ella. En una carta anterior al concejo de Villena firmada el 14 de julio en Molina, el Adelantado manifiesta que finalmente se ha recuperado el castillo y que por tanto no deben ya temer nada, así como que todos los daños que han sufrido le serán pagados doblemente como corresponde. Alfonso Yáñez les pide que comuniquen todo ello al doctor Pero Yáñez haciéndole saber además cómo él había enviado con tropas a su sobrino Gonzalo de Soto para que tomase el castillo. Les insta a que hagan pleito homenaje al Alcalde Mayor Pero Fernández de Entrena, hombre fiel y muy leal al doctor, y les comunica finalmente que les defenderá y ayudará siempre "en todas las cosas asy commo a my mesmo". La situación de peligro sufrida por la villa entre mayo y junio de 1440 ha desaparecido ya en septiembre de ese año. La correspondencia se interrumpe. El doctor Pero Yáñez podía pues respirar con tranquilidad. Sin embargo no lo estaba, prueba de ello es que solicitó de nuevo al monarca que le confirmase en la posesión de la villa. Juan II así lo hizo en un albalá firmado en Valladolid el 2 de julio de ese mismo año, en el que le promete bajo juramento que no le quitará Villena mientras no le haga enmienda equivalente por la villa de Granadilla -o Granada como dice el documento- (22). Este testimonio prueba que el doctor Pero Yáñez, hombre que por su cargo estaba perfectamente enterado de todo lo que pasaba en la Corte, no las tenía todas consigo en lo que respecta a la posesión de Villena. $Y$ en efecto poco después, Juan de Navarra al enterarse de la concesión de Villena al doctor, protestó enérgicamente de tal hecho ya que consideraba que la villa le pertenecía según el acuerdo de 1439 y que por lo tanto esa donación encubría una clara usurpación (23). Pero Yáñez temía por tanto que Juan II le arrebatase la villa y la entregase a su primo Juan de Navarra en unos momentos en que de nuevo los infantes habían logrado recuperar el poder en Castilla. Los temores que albergaba Pero Yáñez no eran infundados. Al año siguiente era 
expulsado del Consejo Real con todos los hombres de confianza de don Alvaro de Luna (24). Por poco tiempo, sin embargo, pues un año más tarde la presión de la nobleza que, poco a poco se iba apartando de la política seguida por los infantes temerosos, quizá, de un excesivo predominio del rey de Navarra, obligó a este último a reponer en su cargo a los desterrados (25). Al año siguiente "el golpe de estado" de Rámaga, en palabras del profesor Suárez Fernández, dado por Juan de Navarra cambió bruscamente la situación. Los infantes se convierten en dueños absolutos del poder, y el rey termina por ser un prisionero (26). Pero Yáñez y Pérez de Vivero también son hechos prisioneros y todos los partidarios y simpatizantes de don Alvaro son alejados de la Corte. Los clanes nobiliarios se dividieron en dos bandos que se enfrentaron en la batalla de Olmedo de 1445 en la que fueron derrotados los infantes de Aragón. Sin embargo el doctor Pero Yáñez no pudo conocer esta victoria de su protector Alvaro de Luna pues había fallecido un año antes. Su testamento otorgado en Santa María de Nieva en 1442 ha sido publicado por José María Soler García y de él se conservan dos ejemplares, uno en el Archivo General de Simancas y otro en el Archivo Ducal de Medinaceli (27).

Antes de morir Pero Yáñez que había logrado con grandes dificultades conservar Villena, fundó mayorazgo en 1442 para su hijo Juan en el que incluyó la villa y otras propiedades situadas en Burgos y Zamora (28). En ese mismo año su segunda esposa Juana de Herrera escribió al concejo de Villena informándole de que había enviado como corregidor y alcaide de la villa a su sobrino el bachiller Juan de Ulloa (29). Al año siguiente, el 24 de julio de 1443, el propio doctor envía unas ordenanzas municipales para su villa (30). Pero Yáñez refiere en su informe a la villa que en tiempos pasados hubo algunos debates y contiendas en torno a las personas que debían ocupar los oficios capitulares, sobre el pago de pechos, impuestos, facenderas y otros tributos nuevos, sobre el salario que debían recibir los recaderos que se enviaban al monarca y al señor, y sobre la distribución de las cuotas y gastos que se hacian en la villa. A fin de evitar en lo sucesivo disturbios y problemas concede a la villa unas ordenanzas, un texto legal que recogiese todos esos problemas, les diese una solución y les permitiese regirse y encauzar la diversidad de la vida local. Por su importancia pasamos a estudiarlas en el capítulo siguiente.

\section{LAS ORDENANZAS DE VILLENA}

Las primeras ordenanzas municipales de Villena son muy breves y constan de algunos capítulos interesantes. En primer lugar, el doctor Pero 
Yáñez ordena que su mayordomo Alvar Ruiz no sea elegible para ningún oficio municipal puesto que ya ocupaba un cargo de designación señorial y por tanto su cometido era velar por los intereses de su amo en la villa y no por los de los vecinos. El doctor manifiesta también que se guarden siempre los capítulos de acuerdo firmados por el concejo de Villena cuando Alvar Ruiz en representación de la villa le recibió por señor en 1440, documento éste que por desgracia se ha perdido.

Los capítulos más interesantes de las ordenanzas no son siempre los que se refieren a la elección de los oficios municipales. A fin de evitar elecciones comprometidas y un tanto dudosas que pudieran dar lugar a discusiones e incluso a disturbios en la villa, Pero Yáñez organiza un modelo de elección sumamente original. El cabildo municipal de la villa lo formarían doce personas: dos alcaldes ordinarios, un alguacil, seis regidores, dos jurados y un almotacén. La elección de estas autoridades que servirían los intereses de Villena durante un año quedaría a cargo de los vecinos, pero no de todos ellos sino tan sólo de cuatro hombres buenos sin sospecha, elegidos ocho días antes de San Juan por los oficiales del cabido saliente. A su vez estos cuatro vecinos procederían a echar suertes entre ellos y elegir a dos de los cuatro que serían los encargados y tendrían la gran responsabilidad de escoger a 36 hombres buenos abonados para que sus nombres pudiesen ser incluidos dentro de unos redolines o bolitas de cera. Los electos eran seis para el oficio de alcalde, seis para el de jurado, tres para el de alguacil, tres para almotacén y dieciocho para regidores. Todos estos nombres tendrían la garantía de ser oficiales del cabildo durante un año a través de un curioso procedimiento de elección. Ocho días antes de San Juan se harían seis redolines de cera en los que se incluiría una cédula con el nombre de cada uno de los elegidos para alcalde, otros seis para jurados, tres para alguacil, tres para almotacén y 18 para regidores. Los redolines se pondrían posteriormente en un bacín y de él una persona no propuesta para oficio alguno sacaría dos para alcalde ordinario, uno para alguacil, dos para jurados, uno para almotacén y seis para regidores. Los elegidos jurarían y servirían sus oficios respectivos durante un año. El mismo procedimiento se volvería a utilizar durante los dos años siguientes a fin de que todos los 36 propuestos el primer año desempeñaran los oficios durante los tres años siguientes. Al término de esos tres años se volverian a escoger otros 36 nombres de vecinos por el mismo método para otros tres años. Si uno de los propuestos "finare" antes de haber aceptado el oficio debería ser elegido otro hombre bueno por esas dos personas designadas de entre cuatro y su nombre puesto en el redolín. Cada uno de los oficiales elegidos ejercería su oficio personalmente "saluo si fueren dolientes o no estuuiesen en el termino de la villa, en tal caso deben dejar su tenien- 
te ydoneo a voluntad del concejo". De esta manera el doctor Pero Yáñez para evitar problemas si la elección era anual, organiza un curioso sistema trianual de elección nada democrático puesto que no contemplaba a la totalidad de los vecinos de la villa sino tan sólo a unos pocos que con toda seguridad formarían parte de la oligarquía social dirigente.

Las ordenanzas de 1443 recogen también otra serie de disposiciones, algunas también de interés. Así se prohibía al concejo de la villa que impusiese tributos, pechos o derramas sin licencia expresa de don Pero Yáñez. Sólo podrían hacerlo en caso de verdadera necesidad y siempre que esos impuestos no sobrepasasen los 3.000 maravedíes. Por otra parte, el doctor ordena también que se le den $15 \mathrm{mrs}$. de jornal diario al mandadero o mensajero que fuese a la Corte portando cartas del concejo dirigidas al rey o al propio Pero Yáñez. Si el mensajero en cuestión no era peón sino caballero recibiría un salario superior: 25 maravedís diarios. Finalmente por lo que respecta a los gastos realizados por el concejo desde el año 1440 en que pasó la villa a poder de Pero Yáñez y desde este año -1443-en adelante, el doctor ordenó que el cabildo de Villena eligiese a cuatro hombres buenos vecinos de la misma "abonados e pecheros con juramento" para que juntamente con los oficiales examinen las cuentas de los jurados, cogedores o mayordomos de las rentas.

Las ordenanzas de Villena finalizan con la firma autógrafa del doctor Pero Yáñez que al ser letrado en Derecho escribe su nombre en latín: Petrus. El documento en cuestión va rubricado y sellado, en presencia de testigos, con el sello de Pero Yáñez.

\section{LA INCORPORACIÓN DE VILLENA A LOS DOMINIOS DE JUAN PACHECO}

El doctor Pero Yáñez murió en Burgos de edad avanzada a fines de agosto de 1444 (31). En su precioso testamento otorgado en 1442 y publicado recientemente por $\mathrm{D}$. José María Soler que traza en el trabajo ya citado su biografía política y la gran confianza que tenía en él Juan II, Pero Yáñez entre otras cláusulas de gran interés valora Villena en 30.000 florines y crea un mayorazgo con esa villa y otras para su hijo primogénito Juan de Ulloa (32). Sin embargo, los acontecimientos posteriores invalidarían en buena parte la última voluntad de Pero Yáñez pues muy pronto le sería arrebatada por el príncipe Enrique la villa de Villena a Juan de Ulloa. Las causas que condujeron a este evidente despojo han sido bien expues- 
tas por el propio José María Soler y Aurelio Pretel. Soler piensa en efecto que la donación de Villena al doctor Pero Yáñez había sido circunstancial y coyuntural (33). Aurelio Pretel sostiene por su parte que Juan II siguiendo el consejo de su privado Alvaro de Luna concedió Villena al doctor Pero Yáñez para evitar que cayese en poder del rey de Navarra (34). Desde luego la donación de Villena a Pero Yáñez vulneraba lo acordado en el pacto de Toledo de 1436 y aunque el propio Juan II y su hijo el príncipe de Asturias prometieron al doctor varias veces que no le sería quitada la villa sin la debida compensación, pronto se vió que las circunstancias políticas del reino hacían imposible el cumplimiento de tal promesa. Todavía unos días antes de morir Pero Yáñez arrancó al príncipe Enrique la promesa de que no le sería arrebatada Villena ni a él ni a sus herederos sin una enmienda (35). Sin embargo la muerte de Pero Yáñez precipitó los acontecimientos y fue aprovechada por Juan Pacheco, privado del futuro Enrique IV, interesado desde hacía algún tiempo por conseguir para su linaje las tierras que habían formado parte del antiguo marquesado y entre ellas la villa de Villena. Juan Pacheco ambicionaba la villa de Villena desde mucho antes de morir Pero Yáñez. Y así lo había hecho sentir ante el príncipe de Asturias y ante Don Alvaro de Luna. Para conseguir sus propósitos Pacheco llegó a un acuerdo en enero de 1444 con el Condestable Luna, acuerdo que escondía una verdadera confederación contra los infantes de Aragón: ambos personajes se declaraban en las cláusulas de este documento que serían amigos de sus amigos y enemigos de sus enemigos (36). El condestable prometía a Pacheco que lograría del rey la promesa de darle ViIlena o en su defecto 700 vasallos en tierras de la ciudad de Sevilla o de la de Córdoba, donde él prefiriese y asimismo se comprometió a entregarle la villa de Moguer que pertenecía a su esposa María Portocarrero que a la sazón le había usurpado Martín Fernández Portocarrero, hijo de Micer Gilio Bocanegra, señor de Palma del Río (37). Así pues desde el mes de enero de 1444 Pacheco deseaba la villa de Villena. Dos meses más tarde, el 3 de marzo de ese año, Juan II aconsejado por su privado Alvaro de Luna que para acabar con sus enemigos los infantes de Aragón necesitaba del concurso y la amistad del príncipe de Asturias y por tanto de la de Pacheco, concedía a este último Villena con su fortaleza, jurisdicción y rentas y le prometía que se la entregaría dentro de los sesenta días posteriores a la fecha de esa carta (38). Además de concederle Villena, el monarca le prometió al Camarero Mayor del Príncipe "que le amaría mucho y que se fiaría de su persona, haciéndole muchas merçedes, acreçentando su estado e honor, guardando e defendiendo su persona y casa de todo mal e danno, e que nunca solicitaría ni permitiría apartarle de la priuança e lugar que tenia con el dicho sennor Prinçipe don Enrique su fijo". Juan II se aseguraba también que se preocuparía personalmente de entregarle Moguer en esos sesenta días siguientes a la fecha de su carta "en que hará al con- 
de de Niebla que vos dé todo fauor e ayuda para ello e que tomará dicho conde de Niebla si fuese neçesario la dicha villa de Moguer para entregarsela”. En este albalá el monarca pasaba por alto los derechos que a Villena podrían tener tanto su hombre de confianza Pero Yáñez, que en ese momento poseía la villa, como los herederos de este último. Ante la insistencia de Juan Pacheco por apoderarse de Villena, el monarca y don Alvaro de Luna no tuvieron más remedio que ceder. Por eso el doctor Pero Yáñez temía que le arrebatasen la villa a pesar de las promesas que a este respecto le habían hecho Juan II y el príncipe Enrique. El viejo doctor sabía antes de morir que perdería Villena aunque hizo todos los esfuerzos posibles para evitarlo. El propio Juan II intentó a la desesperada que Pacheco en vez de recibir Villena se contentase con 700 vasallos en tierras de Sevilla o Córdoba. Nada sin embargo pudo hacerse frente a la voracidad de Pacheco. El 21 de noviembre de 1444 el príncipe de Asturias en un albalá fechado en Murcia aprovechaba la desaparición de Pero Yáñez para reclamar la villa de Villena "por ser lugar del marquesado de Villena e me pertenesçe por razón de la dote que me fue prometida al tienpo que se concertó mi casamiento con la princesa mi muy cara e amada muger" (39). Cuando otorga el albalá el futuro Enrique IV y su mayordomo mayor Juan Pacheco habían ocupado por la fuerza, tras un duro asedio, la villa y fortaleza de Villena. Los herederos del doctor Pero Yáñez nada pudieron hacer frente al poder del heredero del trono de Castilla. En el albalá anterior el príncipe heredero jura y promete ante su camarero mayor Pedro Girón, hermano de Juan Pacheco, que Juan de Ulloa recibiría una compensación equivalente por la pérdida de la villa. En ese mismo día en que el heredero de Castilla hace saber a su padre que ha tomado Villena para sí, el privado de Juan II, Alvaro de Luna, y Juan Pacheco se comprometen a lograr del monarca una compensación para Juan de Ulloa por la pérdida de Villena (39). El príncipe Enrique y Pacheco no habían tomado Villena pacíficamente sino por la fuerza, despojando a los Ulloa de la posesión de la villa. La usurpación estaba ya hecha. Los Ulloa no se atrevieron a denunciarla. El príncipe Enrique había conquistado Villena para donársela a su favorito. La batalla de Olmedo fue el pretexto y la ocasión idónea para conceder Villena a Pacheco. Juan II y don Alvaro de Luna con el concurso del príncipe de Asturias y de su privado Pacheco lograron derrotar a los aragoneses. El precio impuesto por Pacheco no sólo fue la donación de Villena sino también de otras villas como Sax y Yecla y lo que era mucho más importante, la concesión del título ambicionado de marqués de Villena. En efecto, en las capitulaciones firmadas el 2 de septiembre de 1445 entre Juan II y Alvaro de Luna de una parte y el príncipe Enrique y Juan Pacheco de la otra, se acordó entre otras cosas que se daría a este último una buena compensación si renunciaba a la villa de Agreda que pocos meses antes le había concedido el rey (40). Unos días más tarde, el 13 de septiembre, Juan II fi- 
ja esta compensación en 1.000 vasallos que le serían entregados a Pacheco en la villa de Villena y su tierra, en las de Sax y Yecla y en varias aldeas de la tierra de Alarcón que serían oportunamente separadas de la jurisdicción de esa última villa (41). Pacheco había conseguido su objetivo, más aún cuando el monarca le había concedido el día anterior el título de marqués de Villena (42). Pocos días después un privilegio del príncipe de Asturias otorgado en Almagro confirmaba a su privado la donación que su padre le había hecho de Villena, Sax, Yecla y las aldeas de Alarcón (43). El heredero del trono castellano comisionaba al bachiller Mateo Fernández de Medina del Campo para que fuese a esas villas y contase el número de vecinos que vivían en ellas. El bachiller cumplió escrupulosamente su cometido y así contó 420 vasallos en las villas de Villena, Sax y Yecla y los restantes 580 se escogieron en la tierra de Alarcón (44). Por último Juan II confirmó las posesiones de Pacheco en un solemne privilegio rodado dado en Toro el 6 de abril de 1446 (45). De esta manera Villena se incorpora a los dominios de Juan Pacheco y en su poder permanecerá hasta 1480 en que los Reyes Católicos confiscarán esa villa y otras del marquesado a su hijo Diego López Pacheco. En definitiva tal y como afirma D. José María Soler, la donación de Villena a Pero Yáñez "se había hecho en tiempo de necesidad y con el propósito de revocarla en cuanto el peligro amainase", pero al dar la villa al doctor el monarca vulneró las normas del apanage regio, transgresión ésta que sería bien aprovechada por Juan Pacheco para anexionarse no sólo esa villa sino también muy poco después el marquesado entero, más extenso y poderoso que nunca (46). 


\section{APÉNDICE DOCUMENTAL}

1

[1440], abril 23. Murcia

El Adelantado de Murcia ruega a varios vecinos de Villena que en aras del servicio de su "primo" el doctor Pero Yáñez, señor de la villa, y por el bienestar y sosiego de la misma, se reconcilien con Pedro Fernández de Entrena.

A.- A.D.F., cat. 51. Original, papel. Escritura cortesana.

Pero Serrano e Aluar Royz e Loy Sanchez, amigos, yo el Adelantado vos enbio mucho / saludar. Ya sabedes quantas vezes vos tengo escripto rogandovos que por / seruicio del sennor dotor mi primo vos ploguiese ser en toda concordia e / amistad de Pero Ferrandez e él con vos, de lo qual mi sobrino el bachiller que / ay está tiene cargo e pienso segund quien él es qu'este sea su / deseo que todos biuades en paz e sosiego porqu'el seruicio del dotor / sea guardado e esa villa aya algund espaçio de tantos trabajos / e dannos commo ha padeçido. Yo vos ruego que asy lo fagades, / ca yo escriuo al bachiller sobr'ello e estad a toda su / ordenança en esta amistad porque aya fin, ca bien vedes vos-/ otros que sy non fuese por lo que al dotor toca yo poco tengo que fazer / en los fechos d'esa villa. E pesame porque vosotros diz que aves / fablado algunas cosas que tocan a mi e a mi honor e non sé / qué causa mouio a ellos nin qué atyjaravos es, pero non / curo d'ello que yo sienpre vos toue e tengo por amigos e cosa / mia e tengo de fazer lo que a vosotros cunpla. E Dios / vos dé su graçia. De Murcia a XXIII de abril.

/ $\mathrm{E}$ bien sabedes vosotros que vos dixe que sy Pero Ferrandez quebrantase la amistad / que pusiese con vosotros que yo sería con vos para contra él e asy / lo dixe al dicho Pero Ferrandez en presencia de algunos mis parientes / e asy lo fiziera sy viniera por qué. Alfonso Yannez (rubricado).

(Brevete): De cómo se fizo la trayçion por Pero Ferrandez de Entrena al dotor Periannez.

\section{2}

[1440], mayo 21. Villena.

El concejo de Villena expresa al Adelantado mayor del reino de Murcia su temor de que el alcaide del castillo, Juan Martínez de Mergelina, pudiera alzarse con 
la fortaleza y asimismo le informa sobre otras acciones sospechosas de traición. En consecuencia le ruega que acuda a la villa.

A.- A.D.F., leg. 51. Original, papel. Escritura cortesana.

\section{Sennor:}

El conçejo, regidores, escuderos, ofiçiales e omes buenos de la villa de Villena nos encomendamos en vuestra merçed, a la / qual plega saber que despues que parto Aluar Royz nuestro vezino para vuestra merçed auemos visto e veenos sennales a que esta / vilia se espera seer perdida por causa del castillo, ca sennor veemos que la lenna que estaua en los palaçios Juan Martinez de / Mergelina la a fecho sobir a la fortaleza de alto e asimesmo quantas armas aca en su casa e en casas de otros sus / amigos tenia las ha sobido al dicho castillo, asi ballestas commo escudos e otras armas, e a fecho sobir al dicho castillo a vn / nuestro vezino secretamente que lo non sopiemos que le dizen Berenger Asor e fazele alla adobar truenos e ballestas que alla tiene de omes ve-/ zinos nuestros e non lo dexa deçender de alla. Otrosi estas dichas ballestas e truenos e escudos e lanças e almazen de / viratones non lo quiere tornar cosa d'ello a sus duennos que ge los piden e reparase de viandas e prouisiones e armas / commo dicho es e otros mouimientos muchos que serian largos de escreuir por lo qual estamos muy re(çelo)sos de resçebir mucho / danno. E avn sennor veemos más que anda fablando lo que non acostunbraua con los amigos de los fuera echados e cree-/ mos segund las maneras que deue tratar con ellos. $E$ otrosi veemos mal sennal que la gente de cauallo que vino a Yecla e / corrieron esta villa se eran ydos e son tornados a Yecla e disese que son venidos más e que atienden otros. E d'estas / cosas veemos muchas nouidades de que estamos muy reçelosos, por merçed vos pedimos que vuestra merçed plega de / nos remediar para que estemos en seguro del dicho castillo e ternemos vos en mucha merçed que vuestra merçed plogiese / de venir a lo remediar e si vuestra merçed non puede venir que enbie vna tal persona secretamente para que lo faga, / ca dize que non dará el castillo a ninguna persona nin menos lo acojerá, e vengase este omme delante con otro que vuestra mer-/ çed mandare para que sepamos vuestra venida o de aquel que vuestra merçed enbiare ca sennor pasamos mucho trabajo que / auemos de tener gente de noche aderredor del dicho castillo para lo guardar que non entren ningunas personas e asimesmo / poner recaudo en la villa de gisa que ninguno non duerme en cama. E sennor vuestra merçed plaga que este remedio / sea luego porque de ora en ora faze mouimientos e nouidades e creemos que se açercan las oras. E nuestro Sennor Dios / vos acreçente los dias de la vida con más estado de sennorio.=

De Villena a veynte e vno de mayo.

\section{3}

1440, junio 1.

El Adelantado de Murcia, Alfonso Yáñez Fajardo, ruega al concejo de Villena que ordene a Fernando Alfonso y a Alfonso López que entreguen al alcaide Juan Martínez de Mergelina 5.000 maravedies que tenían en su poder para abastecer y proveer el castillo de la villa. 
Onrrados el conçejo, alcalldes, alguazil, escuderos, ofiçiales e omes buenos de la villa de Villena. Alfonso / Yannez Fajardo, Adelantado mayor del Regno de Murçia e del consejo del rey nuestro sennor, vos enbio / mucho saludar commo aquellos por quien de voluntad tengo de fazer lo que a vuestra onrra cumpla. Fago / vos saber que commo yo he sabido que Fernando Alfonso e Alfonso Lopez, vuestros vezinos, / tienen del recabdador del anno pasado fasta çinco mill maravedies los quales fueron enbar-/ gados en su poder por Nicolas Rodriguez procurador del dotor Per Yannez, sennor d'esa / dicha villa, et por quanto yo he sabido de çierto que Juan Martinez de Mergelina alcayde del / castillo d'esa dicha villa non salle del dicho castillo por lo tener mejor guardado para / seruiçio del dicho sennor rey e del dito dotor e ha menester ser proueydo de algunas / cosas neçesarias al proueymiento e mantenimiento del dicho castillo e porque de cada / dia la dicha villa es corrida por çierta gente de cauallo que açerca d'ella es en algunos / logares, de parte del dicho sennor rey vos requiero e de la mia vos ruego que luego / vista esta mi carta mandedes e apremiedes a los dichos Ferrando Alfonso e Alonso / Lopez que luego den al dicho Juan Martinez de Mergelina, alcayde, los dichos çinco mill marauedies / para forneçer e basteçer de lo que dicho es e si neçesario fuere vosotros / o vuestro mandado tome los dichos marauedies de su poder e los dé al dicho Juan Martinez, alcayde, e / los tomen de su poder por fuerça o en otra manera pues que es seruiçio del dicho / sennor rey, ca su alteza lo avra por bien fecho e su sennoria puede man-/ dar a sus contadores que de qualesquier marauedies qu'el dicho dotor ha de su merçed le sean / descontados. Et si neçesario fuere en la toma que faredes de los dichos çinco / mill marauedies mandad al escriuano por ante quien pasare que encorpore esta carta en la / dicha toma porqu'el dicho sennor rey vea que todo se faze por su seruiçio. Et / porque d'esto seades çiertos enbio vos esta mi carta firmada de mi nombre et / sellada con mi sello.=

Fecha a primero de junio anno de mill e quatroçientos e quarenta annos. Alfonso Yannez (rubricado).

\section{4}

[1440], junio 4. Molina.

Alfonso Yáñez Fajardo, Adelantado mayor del reino de Murcia, anima al concejo de Villena a que se esfuercen en la defensa de la villa y se apresta a enviarles un contingente de hombres de caballo en caso de que fuese necesario. Asimismo les ruega que confien en la persona del alcalde Juan Martínez.

A.- A.D.F., leg. 51. Original, papel. Letra cortesana.

Onrrados conçejo, alcalldes, alguazil, regidores e ofiçiales e omes buenos de la villa de Villena. Alfonso Yannez Fajardo, adelantado mayor del regno de Murçia / e del Consejo del rey, nuestro sennor, vos enbio mucho saludar con voluntad bien presta de fazer las cosas que a onrra vuestra sean. Sabed que / reçebi vuestra carta que me enbiastes e aquella entendida a lo que dezides de la toma que fizieron a 
Aluar Royz, vuestro mensajero, Dios sabe / quánto pesar yo ove d'ello, en espeçial porque quiso yr de Monnouar allá a tan mal recabdo suyo seyendo por mí d'ello mucho / auisado. Pero ya vos escreui con vn correo mio sobre esta razon que deuiades tomar todas esas mugeres e fijos de / los fuera echados que non comiesen sinon pan porque ellas escriuiesen a sus maridos sobre ello e ellos / diesen gritos al gouernador porque soltase al dicho Aluar Royz con todo lo suyo e yo so mucho marauillado / d'él que le aprouecha tenerlo preso. Otrosi plogome mucho porque me dizen estos mançebos que enbiastes vn mensajero al dotor sobre este fecho. E asy mismo demas de la carta mia que escreui al dicho dotor que enbiastes con Çalameda, enbié vn / correo yo de acá a más andar enbiandole dezir que tan solamente ouiese vn aluala del rey para que su merçed / me enbiase mandar que yo anparase e defendiese esa villa. $\mathrm{E}$ con el dicho Aluar Ruyz escriuia yo al dotor / sobre ella más largamente para que vosotros le enbiasedes la carta porque fue asaz danno ser tomadas aquellas / cartas. Pero bien tengo qu'el dicho Çalameda vos sera ya llegado e el mi correo non puede tardar quatro o çinco / dias. Por ende yo vos ruego mucho que non enbargante el trabajo grand en que estades, que vos esforçes / bien e vos defendades lo que mejor que ser pueda e me escriuades luego lo qu'el dicho dotor vos escriuia. / E eso mismo sy esa gente que es contra vosotros faze pertrecho para estar ay, que non puedo dezir por qué se faze / eso saluo por vna razon la qual non vos puedo escriuir que non se puede tardar ocho dias que non / se descubra. E en tanto yo terné aperçebidos çierta gente de cauallo para vos enbiar sy esa gente / ay se detiene. E eso mesmo atenderé vuestro correo o el mio, el que ante llegare, ca deuedes ser / çiertos que yo paso tan grand pena en mi voluntad commo vosotros e más e non vos enbiar luego / la gente que yo querria por todas las razones que me escriuis porque yo so obligado a vosotros / ca non lo puedo negar. $E$ en tanto ruegovos que vos abengades bien con el alcallde Juan Martinez e / que non pongades en él sospecha ninguna que ya vos lo escriui dos vezes o tres e las dos vezes / fueron tomadas las cartas, ca yo so fiador d'él. E luego me escriuid d'esto. E Dios vos aya / en su guarda.=

De Molina a quatro de junio.=

Otrosi a las otras nueuas que dizen de venir / más gente d'armas non lo creades.

Alfonso Yannez (rubricado).

\section{5}

[1440], junio 4. Molina.

El Adelantado mayor de Murcia hace saber a Pedro Fernández que eran falsos los rumores de la gente de armas que se dirigía a Villena y asímismo le tranquiliza en sus sospechas de que el alcaide del castillo pudiera traicionarles.

A.- A.D.F., leg. 51. Original, papel. Escritura cortesana.

Pero Ferrandez, amigo. Yo el Adelantado vos enbio mucho saludar. Sabed que reçebi vuestra carta e eso mismo la del conçejo a la qual respon-/ do segund veredes largamente. Otrosi vi la otra que vos enbiaron vuestros parientes e amigos de 
Almanza e plogome / mucho de su buena voluntad, pero, sed çierto que de lo que les fue dicho de la gente d'armas que viene que es la mayor mentira / del mundo, que yo he auido cartas de Toledo e de la parte de Ocanna que non es nada saluo famas que echa Mosen Diego / e asy enbió acá a perçebir todos los logares de la Orden de Santiago fasta Carauaca, los quales non yran a su / mandado. Otrosi a lo que dezides que vos fago estar atribulados con ese castillo, Dios sabe quanto me pesa / porque conozco que vos mesmo buscades esta tribulaçion dias ha. $\mathrm{E}$ agora poniendo sospechas e difamando / ese omme que tenia vendido el castillo lo qual non ha seydo nin es asy verdad e el omme que más deuiera / guardar esta difamaçion soes vos. E por esta razón pudiera ser que ese omme con desesperaçion $e$ sentimiento / de tales difamaçiones, fiziera o fiziese cosa con que vos prinçipalmente fuesedes destroydo e perdi-/ do e la más d'esa villa. E esto vos tengo escripto tres vezes e las dos supe que fueron tomadas / las cartas e ruegovos que esto tenpres mucho. E plaziendo a Dios muy ayna aquellos que escriuistes vos / acá o otros por mi mandado yran commo cunple en vuestro socorro. E por ende me escriuid luego con el / dicho Aluar Royz vos enbiaua dezir muchas cosas açerca d'estos fechos que non se pueden escriuir a vos / e a Luy Sanchez. E eso mesmo me escriuio Juan Martinez que non dexauades sobir a él ningunos parientes suyos / e amigos, non lo deues fazer saluo que suban los que quisieren, que yo le he escripto e él lo que cunple. E por / ende esforçadvos bien que avnque agora sufrades algo, todo sera en vuestra onrra e bien e prouecho e / d'esa villa e esta carta mostradla a Luy Sanchez. E Dios vos aya en su guarda.=

De Molina a quatro de junio.

Alfonso Yannez (rubricado).

\section{6}

[1440], junio 30. Molina.

El Adelantado de Murcia informa al doctor Pero Yáñez sobre la traición del alcaide del castillo Juan Martínez de Mergelina y de los daños y talas que ello había supuesto para la villa de Villena y asimismo le incita a que prenda al traidor, que habia huido a Aragón para unirse a las tropas de Juan de Navarra, y lo ejecute.

\section{A.- A.D.F., leg. 51. Original, papel. Escritura cortesana.}

Sennor dotor. El Adelantado Alfonso Yannez Fajardo, me encomiendo en vuestra graçia. / Bien creo que avredes sabido de las talas e danno que vuestra villa de Villena ha res-/ çebido e de los tratos de aquel malo aleuoso de Juan Martinez de Merjelina troxo con el / gouernador Mosen Diego por vender el castillo e la villa, por lo qual ouo de / acaesçer todo este danno. E pensando que aquél estaua leal commo deuia ser, yo / non remedié luego en ello commo se pudiera fazer. E atendiendo respuesta vuestra / de la carta que vos enbié con el correo de pie que vos enbio Villena la primera vez e / por su tardança grand que fizo e por otros fechos que acá en este regno de Murçia / se mouian contra el serviçio del rey que el dicho Mosen Diego nunca en al se / trabaja fasta agora que veya que la dicha villa se yua a perder e destruyr del / todo, aderesçaua de enbiar allá çiertos omes de cauallo por atajar la maldad de a-/ quel traydor, vuestro alcayde e mio 
que fue diez e ocho annos. E en esto llegó a la dicha villa el bachiller Alfonso Ferrandez de Leon con las prouisiones que sabedes del rey, nuestro / sennor, por vertud de las quales derramó la gente que ay estaua sobre la villa / faziendo todo mal e danno en los panes e huertas e trabajandose por entrar / en el castillo, lo qual les defendian e defendieron commo buenos omes Pero Ferrandez (.- - - ) (47) / dicho Pero Ferrandez con él e segund paresçe despues qu'el dicho Juan Martinez ha visto que non / pudo conplir su maldad, salió ayer miercoles fuyendo del castillo ençima de / vn roçin fasta Atudere, lugar de Aragón que es a dos leguas de ay. E he sabido / del dicho bachiller e de otros a quien lo dixo que auia voluntad de se yr con otros / del gouernador al rey de Navarra e a vos por se escusar de la trayçion que te-/ nia tratada e acometida. Por lo qual sennor dotor cunple mucho a serviçio / del dicho sennor rey e a honra vuestra que ese omme sea bien preso en vuestro poder fasta que / entregue el dicho castillo al dicho Pero Ferrandez, vuestro alcallde, o a quien vos mandare-/ des. Commo quiera que yo he mandado de vuestra parte al dicho Pero Ferrandez e al conçejo de la / villa que por quantas vias e maneras pudieren tomen e se apoderen del dicho casti-/ llo e que luego vos lo fagan saber ca se esto se cunple bien, podes ser seguro que / la villa estara en buen recabdo e que se defenderá de qualquier gente que contra ellos / vinieren. E avnque lo mandare qualquier persona por grande que sea con el fauor / e ayuda que yo les daré, avnque faga la parte donde yo esto se traen por parte de allá, algunos tratos e maneras que yo tengo asaz que fazer, espeçialmente por causa / de la pestilençia que ha començado en esta çibdad de Murçia por la qual yo non puedo / estar en ella. E sennor dotor, se ese traydor vos fuere entregado avnqu'el castillo / cobredes, seria todavia mucho serviçio del rey e vuestro que por justiçia fuese muerto / commo traydor. E Dios aya sienpre en su guarda.=

De Molina, XXX de junio.

Alfonso Yannez (rubricado).

\section{7}

1440, julio 2. Valladolid.

Juan II promete al doctor Pero Yáñez que en el caso de que tuviese que hacer entrega de la villa de Villena a Juan de Navarra, según había sido acordado entre ambos monarcas, él no sería despojado del señorío y de la posesión de la villa hasta tanto no le hiciese una enmienda equivalente.

A.- A.D.F., catálogo 51, núm. 3. Original, papel. Sello de placa. Letra cortesana.

Don lohan por la graçia de Dios, rey de Castilla, de Leon, de Toledo, de Gallizia, de Seuilla, de Cordoua, de Murçia, de lahen, del Algarbe, de Algezira / e sennor de Vizcaya e de Molina. Por quanto yo di por juro de heredad para sienpre jamas a vos el doctor Peryanez, mu oydor e / referendario del mi Consejo, la villa de Villena con su castillo e fortaleza e justiçia e juridiçion alta e baxa e mero e mixto / inperio e vasallos e rentas e pechos e derechos e penas e calonnas e tierra e termino e distrito e con todas las otras cosas / pertenesçientes al sennorio de la dicha villa de Villena e su tierra para que la ouiesedes e ayades por vuestra para vos e para vuestros / herederos e subçesores en emienda e equivalençia de la villa de 
Granada e de su tierra, de que vos yo oue fecho merçet por juro / de heredad con la justiçia e juridiçion çeuil e criminal e mero mixto inperio e rentas e pechos e derechos pertenesçientes / al sennorio d'ella e con todas las otras sus pertenençias, la qual vos teniendola por vuestra e commo vuestra por virtud de la dicha merçet / que d'ella vos fize la vos dexastes libre e desenbargadamente por mi mandado al infante don Enrique, maestre de Santiago, / mi muy caro e muy amado primo, a quien la yo mandé segunt que todo esto susodicho e otras cosas más largamente se contiene / en çiertas mis cartas que en esta razón vos yo mandé dar firmadas de mi nonbre e selladas con mi sello. E por quanto el rey don / Johan de Nauarra, mi muy caro e muy amado primo, dize que la dicha villa de Villena le es obligada e que pasó çierto tracto / entre mí e él, por el qual dize que ge la yo deuo dar. Por ende por la presente seguro de sy ecaesçiere que yo aya de / dar la dicha villa de Villena al dicho rey de Nauarra, mi primo, o ge la mandare restituyr diziendo que estaba en posesion / d'ella e que fue despojado d'ella o por otra qualquier causa o razon que sea o ser pueda, que vos non seredes priuado nin / despojado de vuestra posesion de la dicha villa fasta que primeramente vos sea por mí fecha enmienda equiualente de la dicha / villa de Granada e de los vasallos e renta d'ella fasta que primeramente ayades e tengades paçificamente la posesion de la dicha equivalençia. $E$ que ante nin otra manera yo non vos mandaré desapoderar nin priuar nin podades ser nin seades desapoderado / nin priuado de la posesion de la dicha villa de Villena nin de cosa de lo susodicho a ella pertenesçiente e anexo, non enbargante / qualesquier mis cartas que yo aya dado o diere avnque contengan qualesquier clausulas derogatorias e otras firmezas e avnque / sean de primera e segunda jusion o allende e avnque faga mençion espeçial o general d'esta mi carta o de lo que en ella conteni-/ do e avnque se diga proçedi de mi çierta çiençia e propio motu e poderio real absoluto o en otro qualquier manera / que sea o ser pueda, por quanto mi merçet e voluntad es que todavia se faga e cunpla primeramente todo lo contenido en / esta mi carta e asy lo seguro por ella. E mando al prinçipe don Enrique, mi muy caro e muy amado fijo, e a los infante, / duques, condes, ricos omes, maestres de las ordenes, priores, comendadores, subcomendadores, alcaydes de los castillos e casas fuer-/ tes e llanas e a los mis adelantados e merinos e a todos Ion conçejos, alcalles, alguaziles, regidores, caualleros, escuderos e omes / buenos de todas las çibdades e villas e lugares de los mis regnos e sennorios e a otras qualesquier personas mis subditos e / naturales de qualquier estado o condiçion, preheminençia o dignidad que sean e a qualquier o a qualesquier d'ellos que lo guarden e / cunplan e fagan guardar e conplir en todo e por todo segunt que en esta mi carta se contiene e non vayan nin pasen nin con-/ sientan yr nin pasar contra ello sin contra cosa alguna nin parte d'ello, mas que vos defiendan e anparen en la tenençia de la di-/ cha villa con todas sus pertenençias e non consientan que seades desapoderado nin priuado nin despojado d'ella nin de cosa / alguna de los susodicho vos nin vuestros herederos e subçesores despues de vos, non enbargante qualquier cosa que en contrario / sea o ser pueda fasta tanto que primeramente vos yo aya fecho la dicha emienda equiualente e ayades e tengades paçi-/ ficamente la dicha equiualençia. $E$ los vnos nin los otros non fagan ende al por alguna manera so pena de la mi merçet e de priua-/ çion de los ofiçios e de confiscaçion de los bienes de los que lo contrario fizieren para la mi camara. E demas mando al omme que les / esta mi carta mostrare que los enplaze que parescades ante mí en 
la mi corte doquier que yo sea del dia que los enplazare fasta / quinze dias primeros siguientes so la dicha pena, so la qual mando a qualquier escriuano publico para que esto fuere llamado / que dé ende al que la mostrare testimonio signado con su signo porque yo sepa en commo se cunple mi mandado.=

Dada / en la noble villa de Valladolid dos dias de jullio anno del nasçimiento de nuestro Sennor thesu Christo de mill e / quatroçientos e quarenta annos.

Yo el rey (rubricado).

Yo el doctor Fernando / Diaz de Toledo, oydor e referendario del rey / e su secretario, la fize escreuir por su mandado.

(Brevete): Sobre la carta de la villa de Villena al dotor Periannez sobre la contienda del rey de Nauarra.

\section{8}

[1440], julio 14. Molina.

El Adelantado de Murcia asegura al concejo de Villena que siempre lo socorrerá y lo tranquiliza pues el castillo ya estaba en su poder y el traidor Juan Martínez se hallaba lejos. Les garantiza que todos los daños recibidos les serían pagados con el doble y les anima a que escriban al doctor Pero Yáñez sobre la toma del castillo y la parte que en la misma habia tenido él.

A.- A.D.F., leg. 51. Original, papel. Escritura cortesana.

Honrrados conçejo e alcayde e ofiçiales e omes buenos de la villa de Villena, / el Adelantado Alfonso Yannez Fajardo e del consejo del rey nuestro sennor vos enbio mucho / saludar. Vi la carta que me enbiastes con Gonçalo de Soto, mi sobrino, e aquella / entendida, deues ser çiertos que yo vos tengo de ayudar e defender en todas las / cosas asy commo a mí mesmo, commo quiera que por guerra de Dios pues que ese castillo / es en vuestro poder e de fuera aquel traydor desconosçido de Juan Martinez non deues temer / ninguna cosa ca todos los dannos que aves resçebido vos seran pagados con el / doblo e aquel gouernador que lo mando fazer lo pagara con las setenas a avn / librará bien sy asy libra e por ende esforçad vos bien e todavia guardad a a-/ quella tregua qu'este bachiller que vino por el rey puso entre vosotros e si algo / fizieredes sea en vuestra defensa si vuestros contrarios lo quebrantaren tomando-/ lo por testimonio. Otrosi luego que se tomó el castillo deuieredes enbiar / vn correo a más andar al dotor a la fazer saber la toma del dicho castillo e de / commo yo enbié sobr'ello allá al dicho Gonçalo de Soto, mi sobrino, a lo tomar / e que tomase pleito omenaje por él a Pero Fernandez d'Entrena, su alcalde mayor, / e de commo estades bien esforçados para su seruiçio e que procure con el rey / nuestro sennor de commo vos sean pagados e enmendados todas las tomas que vos / son fechas e robos, e el dicho Gonçalo non me sopo dezir si escreuistes e so / marauillado de vosotros en non me lo enbiar dezir. E eso mesmo deuierades / enbiar al dicho dotor la carta mia que lleuó Pero Fernandez e d'esto me escreuid luego qu'es / lo que fezistes o auedes fecho. E Dios vos aya sienpre en su guarda. $=$

De Molina / XIIII de jullio. Alfonso Yannez (rubricado). 
[1440], septiembre 13. Murcia.

Alfonso Yáñez Fajardo, Adelantado de Murcia, envía a Luis Sánchez a la villa de Caudete para que se informe de varios asuntos referentes a robos de ganados en la comarca así como de la cabalgada que se había refugiado en dicha villa.

A.- A.D.F., cat. 51. Original, papel. Escritura cortesana.

Loys Sanchez, amigo. Yo el Adelantado vos enbio mucho saludar. Sabed que sobre el / ganado que fue traydo de Cabdete, çiertos bueyes, yo escriuo al conçejo e ofiçiales / de la dicha villa segund veredes por vna letra que les enbio. E otrosi les enbio / dezir en commo vos enbio a la dicha villa para saber e vos ynformar de los / dezires e de lo de la caualgada que se dezia ser acogido en Cabdete e que vos / ayan por recomendado. E otrosy les enbio siete bueyes que se fallan acá de los / que fueron traydos que se non fallan más avnque yo les escreui que se falla-/ uan nueue e vna vaca, todavia ternedes en vuestro dezir lo que cunpla en escu-/ saçion mia. E por la forma que les escriuo en todo vos ruego ansy en vno / commo en otro, fagades e tengades manera commo los fechos vengan en buena / espidiçion e execuçion segund que sé que lo farades. E otrosi allá enbio dos cartas / sobre el ganado que fue leuado de los de Yecla, vna para el gouernador e ba- yle de Valencia e otra para Xatiba tengase la manera que cunpla sobre lo / qual escriuo a Pero Ferrandez para que vn omme vaya a lo soliçitar. E otrosi vos / enbio la carta de Cabdete que me enbiaron porque de todo seades bien infor-/ mado. Çerraredes la carta que va para Cabdete las nueuas que yo sé de / Corte son buenas e espeçiales commo cunplen e de cada dia se esperan / mejores segund los fechos van. Todavia tened manera de vos luego / partir para la dicha villa de Cabdete e venido, enbiadme luego dezir / por largo lo que auedes fecho con la ynformaçion que avredes, porque vos çer-/ tifico que en todo vno e otro commo quiera que sea tengo de tener manera / que los damnificados e robados sean satisfechos de los logares que han / dado logar a las tales tomas e robos e non quieren administrar justi-/ çia. E Dios vos aya en su guarda.=

De Murcia a treze dias de setienbre.=

E fio / por Dios que los tienpos vernan tales porque en todo se faga la execuçion que cun-/ pla. E ternedes manera con la dicha villa en commo pues el omme que allá tienen / preso de los que troxieren los bueyes fue leuado e tomado de termino de Almanza / que sea suelto e deliberado.

Alfonso Yannez (rubricado).

\section{0}

1443, julio 24. Resueros, aldea de Arévalo.

Ordenanzas dadas por el doctor Pero Yáñez a la villa de Villena para la elección de los oficios concejiles.

A.- A.D.F., catálogo 51, núm. 11. Original, cuaderno de papel de dos folios. Escritura cortesana. 
(Fol. 1r) Yo el dotor Pero Yannez, sennor de Villena, oydor e refrendario del rey / nuestro sennor e del su consejo, enbio mucho saludar a vos el conçejo, / alcalldes, alguazil, escuderos, ofiçiales e omes buenos de la dicha villa / de Villena que agora son o seran de aqui adelante commo aquellos a quien / amo e de quien mucho fio. Sabed que yo so informado que en / esa dicha villa en tienpos pasados ha avido algunos debates sobre / el fecho del poner de los ofiçios de cada vn anno e eso mismo / sobre el derramar pechos e fazenderas e poner otros tributos / nueuos e eso mismo sobre el enbiar mandaderos al rey / nuestro sennor e a mí sobre algunas cosas nesçesarias sobre / el salario que dauan o deuian dar a los dichos mandaderos. / Otrosí sobre las cuentas de las distribuçiones e gastos que son / fechos en la dicha villa e sobre otras cosas e diuersas/ cabsas lo qual conviene a mí de proueer porque mi seruiçio e / el bien de la dicha mi villa sea guardado. E por ende ordeno e / mando que agora e de aqui adelante sea seruada (sic) e guardada en todo la via e orden que se sigue:

/ Primeramente çerca de la elecçion de los dichos ofiçios por quanto yo / ove dado orden por los capitulos que enbie a la dicha mi villa con / Aluar Ruyz, mi mayordomo, quando vino a me rescebir por sennor / en nombre de la dicha mi villa, mando que los dichos capitulos en lo / que toca a los dichos ofiçios sea guardado e cumplido. E porque / en la dicha elecçion de los dichos ofiçios non sea cabsada culu-/ sion nin parçiallidate, mando que de cada vn anno se tenga esta orden / que non sea dado ofiçio alguno de la villa al que agora es o será mi / mayordomo en la dicha villa que asaz tiene de procurar lo que le / yo mandare.

/ Iten que sean esleydos seys omes buenos para alcalldes para tres annos e / otros seys omes buenos para jurados e tres omes buenos para / alguaziles e otros tres omes buenos para almotaçenes e diez / e ocho omes buenos para regidores. $\mathrm{E}$ que ocho dias antes del dia / de Sant Juan de junio primero que viene de la data d'esta mi carta sean / fechos seys redolines de çera e en cada vno sea incluso el / nombre de cada vno de los seys omes sleydos para alcalldes / e puestos en vn baçin o en otra cosa e dende que por persona que / non sea de los que han de aver ofiçio sean sacados dos redolines / el dicho dia de Sant Juan e aquellos sean alcalldes el primero anno. // (fol. $1 \mathrm{~V}$ ) E al otro anno segiente dia de Sant Juan por la forma susodicha sean / sacados otros dos redolines para alcalldes al dicho segundo anno. E por / esta forma sean sacados los postrimeros dos redolines para alcalldes / el dia de Sant Juan para el postrimero anno.

/ Iten que por esta mesma forma sea fecho en la elecçion del alguazil, / que cada anno sea sacado vn redolin e el que fuere fallado e nombra-/ do en el redolin sea alguazil el primero anno e por esta forma / sea el segundo e terçero anno fasta ser pasados los dichos tres / annos.

/ Inten que eso mesmo sea fecho en la elecçion del almotaçen que del / alguazil.

/ Iten por esta mesma orden sea fecho en la elecçion de los seys / jurados para los dichos tres annos segund que los dichos seys / alcalldes sacados por redolines commo dicho es. / Iten que por esta orden e forma sea fecho de los diez e ocho / regidores que cada anno por el dicho dia de Sant Juan sean saca-/ dos seys redolines para seys regidores de cada anno fasta / conplidos los ditos tres annos. E que todas estas dichas doze personas que han de regir e seruir los dichos ofiçios fagan / juramento segund que es derecho e costunbre de la dicha villa. 
E para se fazer esta elecçion sin culusion nin otro dolo, que / los ofiçiales que son en la dicha villa este dicho primero anno / en ocho dias antes del dicho dia de Sant Juan eslian quatro omes / buenos sin sospecha e estos quatro echen suertes quien la suer-/ te cayere escogan de la villa omes buenos abonados perte-/ nesçientes para que sean nonbrados e puestos en los dichos redo-/ lines e para seruir los dichos ofiçios los dichos tres annos / cada vno para lo que fuere pertenesçiente. E conplidos los / dichos tres annos se torne por la mesma forma a fazer la dicha/elecçion de tres en tres annos para en todos tienpos. E sea entendido / que si qualquier de los que seran elegidos e puestos en redoli-/ nes finare ante de aver açebtado el ofiçio que sea visto por / el registro onde todos los elegidos seran escriptos e que sea / elegido otro omme bueno por los dichos elegidores e puesto en / redolin en lugar del finado. Pero que se entienda que los dos ele-/ gidores en el anno que elegieren non puedan elegir nin nonbrar alguno // (fol. 2r) d'ellos fasta que otros elegidores sean diputados por la forma / susodicha.

/ Otrosi ordeno e mando que qualquier de los sobredichos que fueren ofi-/ çiales asi los alcalldes commo todos los otros fagan por sí mes-/ mos cada vno su ofiçio saluo si fueren dolientes o non fueren en / termino de la villa, que en tal caso dexe cada vno su teniente ydoneo / a voluntad del conçejo e faziendo juramento e non de otra guisa.

/ Otrosi ordeno e mando que agora nin de aqui adelante el dicho conçejo / e ofiçiales de la dicha villa non sean osados de derramar nin re-/ partyr pechos nin otros tributos algunos entre los vezinos / de la dicha villa syn aver mi carta e espeçial mandado mostrando ca-/ bsas neçesarias e en tal caso yo proueré commo cunple a mi seruiçio / e al bien e poblamiento de la dicha villa saluo fasta en quantia / de tres mill marauedis.

/ Otrosi en razon de las mandadurias que ovieren a fazer al dicho / sennor rey o a mí sobre las cosas neçesarias, que si ovieren de / aqui enbiar omme de pie que lo enbien informado con capitulos e con / relaçion de mi mayordomo e que le den de jornal cada dia quin-/ ze marauedies e si el caso fuere tan arduo que ayan de enbiar manda-/ dero de cauallo que le den por cada dia veynte e çinco marauedies e non / más, e si el (que) fuere esleydo asi de cauallo commo de pie por manda-/ dero non lo quisier açeptar que lo enbien a mí a su costa que yo / proueré commo cunpla.

/ Otrosí ordeno e mando que asi sobre los gastos e distribuçiones / fechos de tres annos a esta parte commo de aqui adelante para reconos-/ çer las cuentas e dar fin a ellas, que sean tomados quatro omes / buenos de la villa abonados e pecheros con juramento e que en vno con los / ofiçiales tomen cuenta a los jurados, cogedores o mayordomos / o secuten o manden esecutar los alcançes e cosas que no fueron / o seran derechamente gastadas en manera qu'el derecho de la recámara / sea guardado. $=$

Porque vos mando que veades esta mi carta e los capitulos en ellas contenidos e conplidlos e fazedlos conplir en todo / segund se en ellos e en cada vno d'ellos se contiene e non fagades / nin fagan ende al por alguna manera so pena de la mi merçed e de diez / mill marauedies a cada vno por quien fincare de lo asi fazer e conplir / para los mis cofres. E porque sea firme escreui aqui mi nonbre / e rogué al escriuano de yuso escripto que la signase de su signo / e mandela sellar con mi 
sello. Dada en Resueros, aldea de la // (fol. 2v) villa de Areualo a veynte e quatro dias de jullio anno del nasçimiento del Nuestro Saluador Ihesu Christo de mill e quatroçientos e quarenta / e tres annos. Petrus (rubricado).

A lo qual fueron testigos Aluaro de Deça, sobrino del sennor dotor e Pedro de / Mansylla e Andres de Çamora, criados del dicho / sennor dotor. E yo Anton Sanchez de Toro, escriuano / de nuestro sennor el rey e su notario publico en la su corte e en / todos los sus regnos e sennorios que a todo lo sobredicho/ en vno con los dichos testigos presente fuy e vi commo / el dicho sennor dotor escriuio aqui su nombre e por su ruego e mandado lo fize escreuir en estas dos fojas de papel de / pliego entero e en fin de cada plana firmé mi nonbre / e por ende fiz aqui este mio signo (signo) en testi-/ monio de verdat. Anton (rubricado).

\section{1}

1444, marzo 3. Tordesillas.

Juan II concede a Juan Pacheco Villena con su fortaleza y jurisdicción y le garantiza que logrará que el doctor Pero Yáñez, que poseía la villa, se la entregara en el plazo de sesenta días. El monarca le da a elegir entre Villena y 700 vasallos en cualquier lugar de los reinos de Sevilla o Córdoba y asímismo le promete que la villa de Moguer sería restituida a su mujer María Portocarrero.

A.- A.D.F., catálogo antiguo, leg. 5. Original, papel, cuaderno de dos folios. Letra cortesana.

(Folio 1r)

Yo el rey, acatando el linaje e persona de vos lohan Pacheco, camarero mayor del prinçipe don / Enrrique, mi muy caro e muy amado fijo, e considerando los seruiçios que a mí e a él aue-/ des fecho e fazedes de cada dia, por la presente vos prometo que agora e en todo tienpo / vos amaré e fiaré de vos e fare muchas merçedes e acresçentaré vuestro estado e honor e guar-/ daré e defendere vuestra persona, casa e estado e onor a que non padesca mal nin danno nin men-/ gua so ningund color nin cabsa que sea o ser pueda asy de fecho commo de derecho de todas / o qualesquier personas de qualquier estado o condiçion que sean commo quier que a mí conjuntas en qual-/ quier debdo que lo tal quisiesen o quieran fazer nin lo yo fare nin mandaré que se faga nin lo permiti-/re directa nin indirectamente. E porque la espiriençia me ha demostrado e demuestra en / quanto grado auedes seruido a mí e al dicho prinçipe mi fijo en aver estado e / estar con él e en tener aquel lugar e manera que con su persona e en su casa tenedes, vos pro- $/$ meto que nunca sere en vos arredrar del dicho prinçipe mi fijo nin en amenguar el lugar e / manera que con su persona e en su casa tenedes e el allegamiento e el amor que él vos ha e fa-/ ze nin lo mandaré nin consentire que sea fecho, ante todo tienpo sere e procuraré porque vos / sea acresçentado e non en cosa nin parte amenguado nin sere nin lo mandaré nin consentire / que en la su casa nin en los sus ofiçios sea nin esté otra persona alguna que aya aquel lugar / que vos auedes nin que vos digades ser a vos sospechosa. E por acatamiento de los dichos ser-l uiçios que auedes fecho a mí e al dicho prinçipe mi fijo en alguna parte de remuneraçion de aque-/ llos vos fago merçed de la villa de Villena con su fortaleza e sen- 
norio e juridiçion çe-/ uil e criminal mero e misto inperio e con todas las otras cosas al sennorio d'ellas / pertenesçientes por juro de heredad para sienpre jamas. $E$ vos prometo que fare al doctor / Pero Yannez que tiene la dicha villa que vos la dé e entregue e faga dar e entregar con su for-/ taleza a toda vuestra libre e grata voluntad de oy dia de la fecha d'esta escriptura fa-/ sta sesenta dias primeros sigientes e fare que dentro del dicho termino seades obede-/sçido por sennor d'ella e vos libraré e dare los más antes que pueda mis cartas de preuile-/ jos tan fuertes e firmes commo librarse puedan para que ayades la dicha villa e todo lo que / dicho es con arogaçion e derogaçion de leyes, ordenamiento e preuillejos asi de mis regnos e /sennorios commo de la dicha villa o del derecho qu'el dicho doctor aya a ella dispensando / con todo ello de mi poderio real absoluto e supliendo qualquier otro defecto por ma-/ nera que vos ayades la dicha villa. E sy por aventura vos más quisieredes seteçien-/ tos vasallos en qualesquier villas e lugares de tierra de la çibdad de Seuilla o de / la çibdad de Cordoua que vos escogieredes e quisieredes, por la presente vos prometo / que vos fare e fago merçed de los dichos seteçientos vasallos en lugar e emienda / de la dicha villa de Villena e fare que vos sean entregados e vos resçebido por sennor / d'ellos dentro de los dichos sesenta dias que vos ha de ser entregada la dicha villa / de Villena sy la vos más quisieredes e que vos libraré las dichas mis cartas e / preuillejos segund e por la forma que vos prometo de librar para la dicha villa de $\mathrm{Vi}-/$ (fol. $1 \mathrm{~V}$ ) llena e faziendo por manera que en todo caso seades obedesçido por sennor de los dichos / vasallos. E porque a mí commo rey e sennor es notorio e bien asy a todos los grandes / de mis regnos yo soy çierto e sabidor de la grand fuerça que está fecha a donna Maria / de Porto Carrero, vuestra muger, auiendo Pedro de Porto Carrero, su padre, dexado en sus / bienes e herençia la dicha villa de Moger a la dicha donna Maria vuestra muger e a donna / Juana, su hermana, e miçer Gilio, sennor que fue de Palma, commo su tutor e en su / nonbre tomó la dicha villa e la poseyo mucho tienpo e despues dio lugar que donna / Françisca, su muger, por fuerça la tomase apropiandola asy en la qual fuerça continuaron / los dichos miçer Gilio e donna Françisca en tanto quanto biuieron e despues Luys / Bocanegra, su fijo, e agora Martin Fernandez, fijo de los dichos miçer Gilio e donna Françisca. / E da lugar a la tal fuerça nin a pleito nin cogniçion alguna nin a otra razon que enba-/ rgar o dilactar pudiese la entrega de la dicha villa de la dicha vuestra muger pues / el fecho es a mí notorio e yo so çierto e sabidor d'ello seria a mí grand cargo / de conçiençia. Por ende vos prometo e aseguro que fare que la dicha villa de Moger vos sea / dada e entregada a toda vuestra libre e grata voluntad de oy dia de la fecha d'esta escriptura fasta (en blanco) dias primeros sigientes e que fare al conde de Niebla que vos / dé todo fauor e ayuda para ello e sy vos quisieredes fare qu'el dicho conde con mis cartas / e poderes tome la dicha villa e vos la entregue. E asy para auer e obtener la dicha villa I de Moger commo para auer la dicha villa de Villena o los dichos seteçientos vasallos en / la manera que dicha es e toda otra qualquier merçed qu'el dicho prinçipe mi fijo vos ha / fecho de liçençia e consentimiento mio, vos prometo que vos libraré e mandaré dar e dare / todas mis cartas e preuillejos e prouisiones e fauor e ayuda e gente e sueldo tales e tan fuertes e firmes como yo las dy e mandé dar a suplicaçión del dicho prinçi-/ pe para la entrega de los castillos e villa de Molina e de la çibdad de Eçija e más / fuertes sy más fuertes se podran dar e aquellas non reuocaré nin mandaré suspender / su efecto, antes a todo mi verdadero poder las fare e 
mandaré traer a todo conplido / efecto syn en ello poner nin admityr dilaçion nin esebçion nin escusaçion alguna. Las quales / cartas e prouisiones asy mesmo dare e mandaré dar para los condes de Niebla e de Ar-/ cos e para las dichas çibdades de Seuilla e Cordoua e para otros qualesquier que cunpli-/ eren para mejor esecuçion de lo que dicho es. E prometo por mi fe real e juro a Dios e / a Santa Maria e a esta sennal de cruz (cruz) en que corporalmente pongo mis manos e a / las palabras de los santos euangellios e fago pleito e omenaje commo rey vna e dos / e tres veses segund costunbre e fuero de Espanna en manos de lohan de Haro, 1 cauallero fijodalgo, que bien e verdaderamente terne e guardaré e conplire e fare tener e / guardar e conplir todo lo suso dicho e cada cosa d'ello e non verne nin consentire yr / nin venir contra ello nin contra cosa nin parte d'ello en algund tienpo nin por alguna ma-/ nera nin so ningund color nin causa e non pedire nin enbiaré pedir nin inpetrar // (fol. 2r) absoluçion, dispensaçion, relaxaçion nin comutaçion d'este juramento nin de lo en él contenido / al santo padre nin a otro que poder aya puesto que me sea dada e otorgada de su / propio motu çierta çiençia poderio absoluto o en otra manera de aquella non vsaré en todo / tienpo guardaré lo aqui jurado e prometido, en testimonio de lo qual mandé dar e dy esta / mi carta firmada de mi nombre e sellada con mi sello secreto.=

Dada en la villa de / Oterdesyllas tres dias de março, anno del nasçimiento de nuestro sennor / Ihesu Christo de mill e quatrocientos e quarenta e quatro anno.

Yo el rey (rubricado).

Yo Françisco Ramirez de Toledo, secretario del rey, la fize escreuir por su mandado.

(A pie de página): Sello secreto.

\section{2}

1444, noviembre 21. Murcia.

El príncipe Enrique, tras apoderarse de Villena, jura y promete al heredero del doctor Pero Yáñez, Juan de Ulloa, que procuraría por todos los medios a su alcance que Juan II, a manera de enmienda, le hiciese donación de otra villa con tantos vasallos como había en aquélla.

A.- A.D.F., catálogo 51, núm. 3. Original, papel. Letra cortesana. Sello de placa.

Yo el Prinçipe. Por quanto yo mandé tomar e tomé para mí la villa de Villena por ser lugar del marquesado de Villena e me pertenesçe por razon de la dote que / me fue prometida al tienpo que se conçerto mi casamiento con la prinçesa mi muy cara e amada muger, la qual dicha villa de Villena fue del doctor Per Yannez, del / consejo del rey mi sennor, por merçed de juro e heredad que su alteza fizo a él e a sus herederos en henmienda e remuneraçion de la villa de Grana-/ dilla e su tierra, la qual el dicho rey mi sennor le mandó dexar al infante don Enrique al tienpo que entró en aquestos reynos. E agora al tienpo que se tomó la dicha villa / de Villena, era de Juan de Vlloa, fijo del dicho doctor. E porque está en razon qu'el dicho Juan de Vlloa sea satisfecho de la dicha villa de Villena pues la / él tenia e poseya por suyo en vertud de la merçed fecha a su padre de la dicha villa e despues a él con- 
firmada por el dicho rey mi sennor, e asi mesmo / por los muchos e muy sennalados seruiçios qu'el dicho doctor su padre fizo al dicho rey mi sennor, en gualardon de los quales su alteza primeramente le dio / la dicha villa de Granadilla e su tierra e despues en hemienda de aquélla le dio la dicha villa de Villena. Por ende yo commo prinçipe, fijo primogenito / heredero del dicho rey mi sennor, juro a Dios $\theta$ a Santa Maria e a esta sennal de cruz (cruz) e a las palabras de los santos euangelios doquier que estan e fago pleito e omenaje en manos de Pero Giron, mi camarero mayor, cauallero omme fijodalgo, vna e dos e tres vezes segund fuero e costunbre de Espanna, / que a todo mi leal e verdadero poder trabajaré, procuraré e terné manera con el dicho rey mi sennor por tal via que su alteza faga merçed de juro e / heredad de otros tantos vasallos e tierra e jurediçion al dicho Juan de Vlloa e sus herederos e que non çesaré de lo asy trabajar e procurar fasta qu'el dicho / rey mi sennor faga la dicha merçed de juro e heredad de los dichos otros tantos vasallos e tierra e jurediçion al dicho Juan de Vlloa e él aya e tenga / la posesión paçifica de todo ello, e esto será lo más presto que yo podré. De lo qual mandé dar esta mi carta firmada de mi nombre e sellada con / mi sello.=

Fecha en la çibdad de Murçia a veynte e vn dias de nouiembre, anno del Nasçimiento del nuestro Saluador Ihesu Christo de mill e quatro-/ çientos e quarenta e quatro annos. Yo el Prinçipe (rubricado).

Esto prometo commo fijo primogenito del rey mi sennor de procurar e trabajar / commo vos sean dados otros tantos vasallos commo aya en Villena e non más. De mi mano.

Yo Diego Arias de Auila, secretario de nuestro sennor el prinçipe, lo fize escreuir por su mandado.

(Brevete): Seguridat sobre lo de Villena.

\section{3}

1445, septiembre 12.

Juan Il concede el título de Marqués de Villena a Juan Pacheco, mayordomo mayor del príncipe Enrique.

A.- A.D.F., cat. 31, núm. 5. Original, papel. Letra cortesana.

Yo el rey, considerando que a los reyes e grandes prinçipes pertenesçe yllustrar, sublimar e decorar por títulos e altas dignidades sus vasallos e subditos e naturales mayormente / aquellos que bien e lealmente los siruen e son d'ellos dignos por sus linajes e personas, porque quanto los subditos e naturales son más grandes e puestos en mayores dignidades tanto / los reyes e prinçipes son por ello más gloriosos. Lo qual todo acatado e considerado e asy mismo la persona e estado e linaje e lealtad de vos Iohan Pacheco, mi vasallo e del mi consejo / e mayordomo mayor del prinçipe don Enrrique, mi muy caro e muy amado fijo promogenito heredero, e los muchos e buenos e leales e sennalados seruiçios que aquellos onde vos venides fizie-/ ron a los reyes de gloriosa memoria mis progenitores e vos avedes fecho e fazedes de cada dia a mí e al dicho prinçipe, mi muy caro e muy amado fijo, e confiando que lo / sienpre continuaredes e faredes de bien en mejor de aqui adelante. E queriendovos sublimar, ylustrar, decorar e honrrar vuestra perso- 
na e estado e porque a otros sea enxenplo e se / esfuerçen para bien e lealmente me seruir, por la presente vos fago e crio mi marques de Villena. E quiero e mando que de aqui adelante seades llamado e yo por la presente / vos llamo don lohan Pacheco marques de Villena e que gozedes de todas las honras e preheminençias e prerogatiuas e de todas las otras cosas e de cada vna d'ellas que por razon / de la dicha dignidad deuedes aver e vos deuen ser guardadas e las ayades e vos sean guardadas bien e conplidamente segunt que más e e mejor son e deuen ser guardadas e se acostun-/ braron guardar a todos los otros que fasta aqui han e ovieron la tal dignidad. E por la presente e con ella vos envisto en la dicha dignidad e título e vos do la posesion e casi posesion d'ella e mando al dicho prinçipe mi fijo e a los duques, condes, perlados, marqueses, ricos omes, maestres de las ordenes, priores e a los del mi consejo e oydores de la mi avdiençia e al mi chançeller mayor e notarios e alcalldes e alguaziles e otros ofiçiales de la mi casa e corte e chançelleria e a los comendadores, subcomendadores, alcaydes de los castillos e casas / fuertes e llanas e a todos los conçejos, alcalides, alguaziles, regidores, caualleros, escuderos e omes buenos de todas las çibdades e villas e logares de los mis regnos e sennorios e a todos / los otros mis vasallos de qualquier estado o condiçion, preheminençia o dignidad que sean e a qualquier o qualesquier d'ellos, que vos ayan e resçiban por mi marques de la dicha Villena. / E que el dicho mi chançeller e el mi notario mayor de los preuillejos rodados e los otros mis ofiçiales que estan a la tabla de los mis sellos pongan e asienten en la tabla de los dichos / mis preuillejos en el logar e grado e regla deuidos a la dignidad que vos yo asido e que todos los sobredichos e cada vno d'ellos guarden e fagan guardar a vos el dicho don lohan / Pacheco mi marques bien e conplidamente todos los honores e preheminençias e graçias e prerrogatiuas que por razon de la dicha dignidad deuedes auer e vos deuen ser guardadas segunt / que mejor e más conplidamente por razon de la dicha dignidad se guardaron e deuen guardar a cada vno de los otros marqueses que fasta aqui fueron e son en mis regnos. E los vnos / nin los otros non fagan ende al por alguna manera so pena de la mi merçed e de priuaçion de los ofiçios e de confiscaçion de los bienes de los que lo contrario fizieren para la mi camara. $=$

/ Fecho doze dias de setienbre, anno del nasçimiento de nuestro Sennor Ihesu Christo de mill e quatroçientos e quarenta e çinco annos.=

Yo el doctor Fernando Diaz de Toledo, oydor / e referendario del rey e su secretario, lo fize escreuir por su mandado.

Yo el rey (rúbrica). 


\section{NOTAS}

(1) SANZ, M.ํa José. "El señorio de Villalonso. Aproximación diplomático-histórica", El Pasado Histórico de Castilla y León, volumen I. Edad Media, Burgos, 1983, p. 223.

(2) SOLER GARCíA, J.M. " "La donación de Villena al Dr. Periáñez en 1440", Studia Histórica in honorem Vicente Martínez Morellá, Alicante, 1985, p. 434.

(3) Ibidem, p. 434.

(4) Archivo Ducal de Frías (en adelante A.D.F.), sección Velasco, leg. 99, n.⒒ Documento otorgado en Valladolid el 12 de octubre de 1398.

(5) SOLER, J.M. ${ }^{\text {a }}$ art. cit., p. 434.

(6) Sobre estos personajes y en especial sobre la figura del contador Pérez de Vivero resulta de interés el trabajo de Alfonso Franco Silva "Alfonso Pérez de Vivero, contador mayor de Juan II de Castilla. Un traidor y su fortuna", Hispania, XLVII (1987), pp. 83-116.

(7) A.D.F., catálogo antiguo, leg. 51, núm 3. Ver a este respecto Pilar León Tello, Inventario del Archivo de los Duques de Frías. II. Casa de Pacheco, Madrid, 1967, p. 267 y ss.

(8) PRETEL MARÍN, A. "Algunas acciones militares de Albacete y su comarca en las luchas de los infantes de Aragón (1421-1444)", Al-Basit. Revista de Estudios Albacetenses, $2^{\mathrm{a}}$ época, año VII, n.ㅇ 10, abril 1981, p. 33.

(9) PASTOR ZAPATA, J.L. "Un ejemplo de apanage hispánico: El señorío de Villena (1250-1445)", Revista del Instituto de Estudios Alicantinos, 31, Alicante, 1980, pp. 15-40.

(10) MITRE FERNÁNDEZ, E. "Señorío y Frontera (el marquesado de Villena entre 1386 y 1402)", Murgetana, XXX, 1969.

(11) Ibidem y Aurelio Pretel Marín. "En torno a la incorporación del Marquesado de ViIlena a la Corona castellana", Al-Basit, 6, 1979. Ver a este respecto Pero López de Ayala. Crónica de Enrique III, tomo LXVIII de la B.A.E, Madrid, 1953, p. 256.

(12) PASTOR ZAPATA, J.L. "Un ejemplo de apanage hispánico ...", pp. 28-30. Y en especial Fernán Pérez de Guzmán, Crónica de Juan II, año 1420, cap. II, p. 380, cap. XXI, p. 388 y cap. XXIV, p. 389, año 1421, cap. XVI, pp. 404-405, caps $V$ y VI, pp. 400-401, cap. X, p. 402 y cap. XI, p. 402.

(13) PASTOR ZAPATA, J.L. "Un ejemplo de apanage histórico ...", p. 30; PRETEL MARÍN, A. "Algunas acciones militares de Albacete ...", pp. 26 y 27. Ver a este respecto lo que manifiesta el cronista de Juan II Fernán Pérez de Guzmán en su obra ya citada, año 1436, cap. V, p. 529. 
(14) A.D.F., catálogo antiguo, leg. $51, \mathrm{n} .{ }^{\circ} 3$. El documento en cuestión lo publicamos en el apéndice.

(15) A.D.F., catálogo antiguo, leg. $51, \mathrm{n} .{ }^{\circ} 3$.

(16) Ibidem.

(17) Ibidem.

(18) PRETEL MARÍN, A. "Algunas acciones militares ...", pp. 33-37.

(19) Se encuentran en el legajo 51 sin enumerar.

(20) PRETEL MARÍN, A. "Algunas consideraciones militares ...", p. 30.

(21) Ibidem, p. 30. Sobre este personaje resulta de gran interés el trabajo de Juan Torres Fontes, "Los Fajardo en los siglos XIV y XV", Miscelánea Medieval Murciana, 1978, p. 146.

(22) A.D.F., catálogo antiguo, leg. 51 n. ${ }^{\circ} 3$.

(23) Ibidem.

(24) El príncipe de Asturias, en tratos por entonces con Juan de Navarra, exigió a su padre que expulsase a los tres funcionarios citados "porque él veía que andaban en su Consejo ciertos hombres que no cumplían a su servicio ni a pro e bien de sus reynos que allí anduviesen". Sin embargo, a lo largo de 1441 continúan presentes en la Corte, pues les cita con frecuencia en ese año el cronista Pérez de Guzmán; por ello es muy posible que ese destierro fuese muy benigno, quizá tan sólo de algunos meses, Crónica de Juan II, año 1440, cap. XIII, p. 565, y año 1441, cap. XXVIII, p. 586.

(25) PÉREZ DE GUZMÁN, F. Crónica de Juan II, año 1442, cap. VII, pp. 608 y 609. SUÁREZ FERNÁNDEZ, L. Nobleza y Monarquía, Valladolid, 1959, pp. 113-114.

(26) Los hechos que condujeron al golpe de estado de Rámaga son narrados de esta manera por el cronista: "Estando en Rámaga en Consejo el Príncipe Enrique notificó al rey que Alonso Pérez de Vivero y Fernán Yáñez de Xerez habían hecho e cometido en deservicio suyo, y en daño de la República e de la paz e sosiego de sus Reynos, muy grandes crímenes y delictos; por ende que suplicaba a su Merced que los mandase prender, e sabida la verdad, hiciese dellos la justicia que debía. E como quiere que desto el Rey rescibió algún enojo, permitió que fuesen presos, e fué entregado Alonso Pérez de Vivero a Ruy Díaz de Mendoza, Mayordomo Mayor, e Fernand láñez a don Enrique, hermano del Almirante ... E fué mandado a todos los oficiales que el rey tenía que eran puestos por mano del Condestable o aficionados a él, que saliesen de la Corte, e así se puso en obra, y el Rey ovo de ser servido de nuevos oficiales puestos por la mano del Príncipe y del Rey de Navarra". PÉREZ DE GÚZMAN, F. Crónica de Juan II, cap. V, p. 613. Continuaban prisioneros en los primeros meses de 1444: "fueron puestos en poder del Almirante, el qual los dió a dos caballeros de su casa, los quales los tuvieron en grillos por algunos días", ibidem, año 1444, cap. I, p. 614.

(27) El testamento publicado por Soler en el artículo ya citado procede del Archivo General de Simancas, en Diversos de Castilla. Leg. 11, n. 38 , y el del Archivo Ducal de Medinaceli, Sección Villalonso ...", nota 7 de la página 224.

(28) SANZ, M. ${ }^{a}$ J. "El señorío de Vollalonso ...", p. 225.

(29) A.D.F., catálogo antiguo, leg. 51, n. ${ }^{\circ} 3$.

(30) Ibidem. 
(31) SOLER, J. Mํ. art. cit., p. 438.

(32) Ibidem, p. 466 y ss.

(33) Ibidem, p. 437.

(34) PRETEL, A. "Algunas consideraciones militares ...", p. 33.

(35) SOLER, J.M. a art. cit., p. 438. El documento en A.D.F., catálogo antiguo, leg. $51, n . \stackrel{\circ}{ } 3$.

(36) La confederación firmada en Talavera se encuentra en A.D.F., catálogo antiguo, leg. 56.

(37) Ibidem.

(38) A.D.F., catálogo antiguo, leg. 5. El albalá va firmado por el monarca en Tordesillas.

(39) A.D.F., catálogo antiguo, leg. 51, núm. 3.

(40) Ibidem.

(41) A.D.F., catálogo antiguo, leg. 56.

(42) A.D.F., catálogo antiguo, leg. 3, núm 18.

(43) A.D.F., catálogo antiguo, leg. 31, núm 5.

(44) A.D.F., catálogo antiguo, leg. 3, núms. 21 y 24.

(45) A.D.F., catálogo antiguo, leg, 3, núm. 25.

(46) A.D.F., catálogo antiguo, leg. 4, núm. 4.

(47) SOLER, J.M. ${ }^{\mathrm{a}}$. art. cit., p. 442.

(48) (...), roto. 